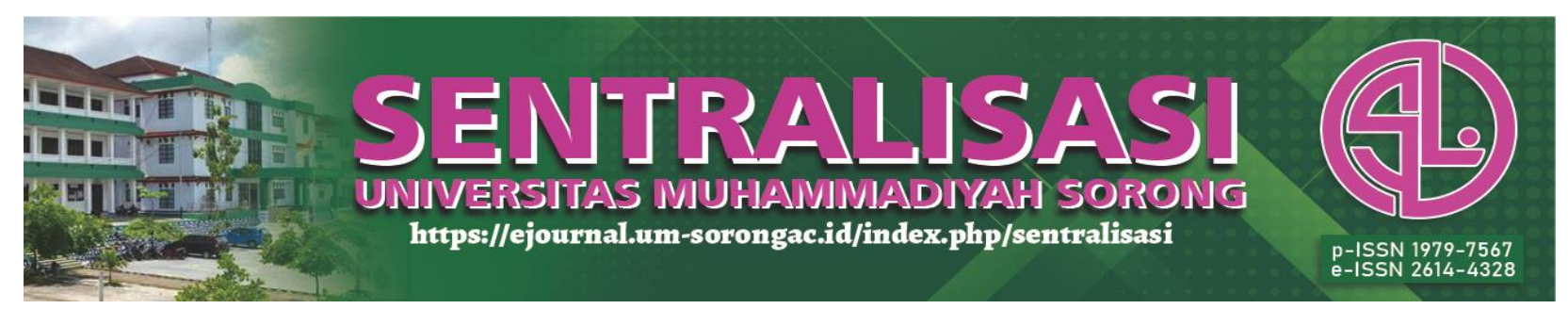

\title{
Strategy of Gamification, Product and Pricing: Does It Matter on Buying Interests of Fore Coffee consumers
}

\author{
Ani Rakhmanita ${ }^{1}$, Ratih Hurriyati ${ }^{2}$, Puspo Dewi Dirgantari ${ }^{3}$ \\ ${ }^{1,2,3}$ Faculty of Economics, Universita Pendidikan Indonesia, Indonesia \\ E-mail : *anirakhmanita@upi.edu \\ * corresponding author
}

direvisi: 7/12/2021 dipublikasikan: 08/01/2022

\begin{abstract}
Abstrak. Penelitian bermaksud untuk mengukur efek dari gamifikasi, variasi produk dan harga pada minat beli konsumen Fore Coffe. Teknik pengumpulan data berupa kuesioner menggunakan link google form yang disebar dibeberapa group whatsapp. Hasil kuisoner tersebut diolah dengan Teknik Analisa Structural Equation Modelling dengan aplikasi SmartPLS. Hasil penelitian menunjukan bahwa Gamifications yang terdapat pada aplikasi fore cofee memiliki pengaruh minat beli konsumen, dilihat dari hasil pengujian hipotesis model yang diajukan. T-nilai untuk variabel gamifikasi sebesar 2.934 lebih besar dari 1.96. Variasi Produk minuman yang terdapat pada aplikasi fore cofee memiliki pengaruh minat beli konsumen, dilihat dari hasil pengujian hipotesis dengan nilai Tstatistic sebesar 3.646 lebih besar dari 1.96. Pengujian hipotesis menunjukkan harga tidak signifikan terhadap minat beli konsumen fore coffe dengan nilai 1.94 lebih kecil dari 1.96. Untuk penelitian berikutnya dapat mengembangkan dengan manfaat gamifikasi lainnya yang dibenamkan pada aplikasi belanja online, sehingga dapat menambah khasanah ilmu pada dunia digital marketing.
\end{abstract}

Kata kunci : Gamifikasi, Minat Beli, Kopi

\begin{abstract}
Abstrak. The aims of this research is to measure the effect of gamification, variety of beverage products and prices on buying interest of Fore Coffee consumers. The data collection technique was in the form of a questionnaire using a google form link that was distributed in several whatsapp groups. The results of the questionnaire were processed using the Structural Equation Modeling Analysis Technique with the SmartPLS application. The results show that the Gamifications contained in the application have an influence on consumer buying interest, seen from the results of testing the proposed model hypothesis. The T-value for the gamification variable is 2,934, which is greater than 1.96. The variety of beverage products found in the coffee application has an influence on consumer buying interest, seen from the results of hypothesis testing with a Tstatistic value of 3.646 which is greater than 1.96. Hypothesis testing shows that the price is not significant to the buying interest of front coffee consumers with a value of 1.94 which is smaller than 1.96. For further research, it can be developed with other gamification benefits embedded in online shopping applications, so that it can add to the repertoire of knowledge in the world of digital marketing.
\end{abstract}

Keywords: Gamification, Buying Interest, Coffee

\section{Introduction}

The trend of consuming coffee is always changing along with the times. Currently, drinking coffeeis part of the millennial generation hangout activity. Competition in the coffee industry is getting faster with the emergence of coffee outlets. The baristas and coffee shop owners continue to carry out the strategy by presenting new innovations. Fore Coffee is one of the new coffee outlets that started its business in August 2018 and currently has grown to have 16 coffee outlets. The business concept used is quite interesting, which is to cross the coffee industry and digital business in 


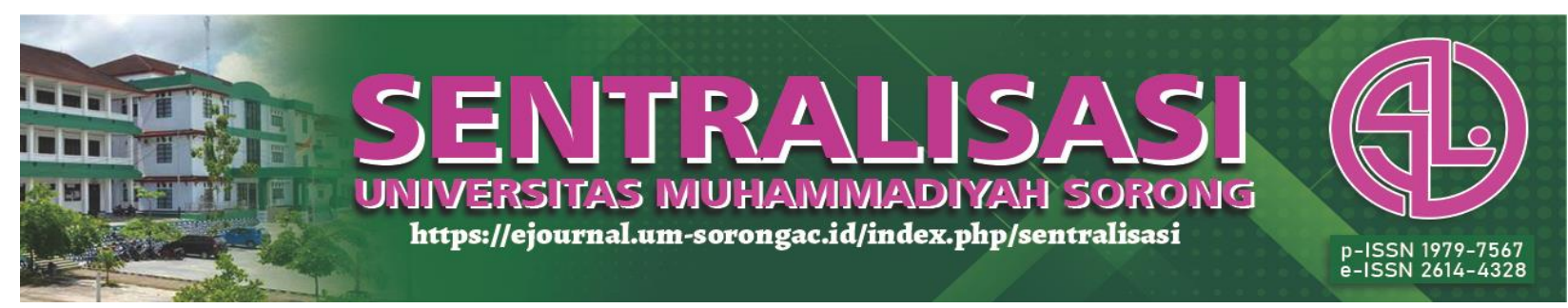

Indonesia. The online-to-offline strategy carried out by Fore Coffee is to integrate mobile application technology to make it easier for consumers to order the products they want to buy. This will make it easier for consumers from various locations to order coffee in a fast time. Fore Coffee invests more in high-tech machines, so that it has not many outlets and only serves online orders. The application of digital fore coffee transformation is not only from processing orders and delivery, but also utilizing technology to make it easier for employees to take care of operational activities in checking inventory stock and making sales report administration.

The presence of COVID-19 in Indonesia in March 2020 forced people to carry out online activities ranging from school, work and shopping. The digital marketing strategy that was first carried out by fore coffee is very profitable. During the pandemic, people are more interested in shopping at online stores. Items often purchased are food and groceri. People's shopping behavior has changed compared to previous buying patterns. Staying at home and buying some food by online is a better option for some today. Therefore, the number of online shops is increasing and the competition between them is getting tougher(Roggeveen \& Sethuraman, 2020) (Alflayyeh et al., 2020). So business people must be able to find new ways to increase their competitiveness in doing business in this digital era, which will determine the success or failure of a business. Business people must conduct an analysis of their consumers' buying interest, including fore coffee. Buying interest is also defined as a plan to buy a product within a certain time (Kotler \& Armstrong, 2012). Buying interest occurs when potential consumers get an attraction to a product they want to have(Zou,T, 2018). There are certain factors that influence consumer buying interest. Business people must know what factors consumers like when they buy. Furthermore, it is necessary to do a way so that consumers are interested in the products that we offer.

Marketing has changed as a result of adaptation to the development of the digital business. (Dunakhe \& Panse, 2020). Gamification is said to be a new way of marketing in the next generation(Zichermann \& Cunnigham, 2011). Gamification can be used as a tool to attract and retain consumers in online stores(Wolf et all, 2020). There have been many online stores that have used the gamification strategy to attract consumer buying interest and consumer retention(Simanjuntak et al., 2016) (Vitkauskaite \& Gatautis, 2018). Basically the game is a fun activity and can be intrinsically motivating to any service mechanism that will implement gamification( Hamari et al., 2014).

In addition to gamification, price is also still seen as a factor that influences buying interest. The price level of beverage products in restaurants basically has a significant impact on consumers' desire to buy(Zhu et all, 2019). Product is also an important variable in influencing purchase intention. Consumers have a wide of choice of product preference and produsen always try to satisfy consumer needs in order to increase sales(Alfred, 2013). Based on the description above, the author intends to measure the effect of gamification, product and prices on consumer buying interest Fore Coffee. 


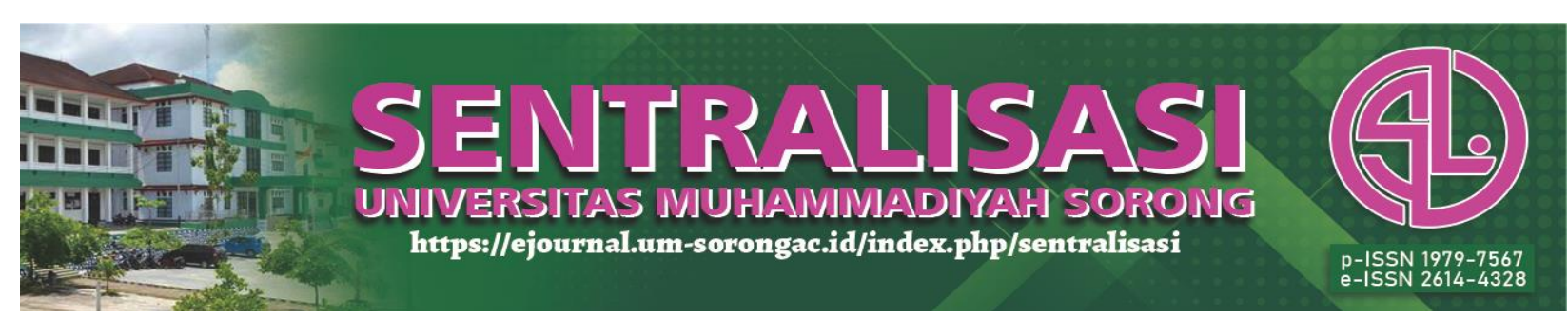

\section{Research Methods}

This study has several variables used, namely buying interest as a variable ( $\mathrm{Y}$ ) or the dependent variable, then for the $\mathrm{X}$ variable or the independent variable, namely gamification (X1), price (X2), and product variations (X3). The population in this study are fore coffee application users who have experienced using fore coffee points. This study uses the Purposive Sampling method used in this study, because random sampling is based on certain considerations that have a focus relationship(Arikunto, 2015).

The data collection technique was in the form of a questionnaire using a google form link that was distributed in several whatsapp groups. List of questions The questionnaire consists of two parts, namely questions related to the characteristics of respondents and questions from each variable which is supported from the previous research In developing the instrument, the author deliberately applies the indicators that have been used by previous studies because they have been tested and validated. Indicators from Kotler are adopted and adjusted for prices and products. The assessment of price indicators, includes a). Price compatibility with quality, b). Price compatibility with benefits, c) affordability of price d). Prices are competitive with other products. While the Product variable is a beverage product offered by Fore Coffee, with indicators that include a) Quality b) Taste Variations, c) Has a characteristic, d) Better quality with competitors. Indicators to measure gamification are adapted and used according to theory ( Hamari, 2015), including: a) Collecting points is very interesting, b) collecting points is a challenge, c) Collecting points to get promos and discounts. Buying interest, using theory (Schiffman dan Kanuk, 2013) the indicators consist of a) Needs, b) Interests c) Searching of Product and d) recommendations. five-point Likert scale was applied in this study. Furthermore, the results of the questionnaire were processed using the Structural Equation

Modeling Analysis Technique with the Smart-PLS application

It is proposed that the model developed in this study is as follows

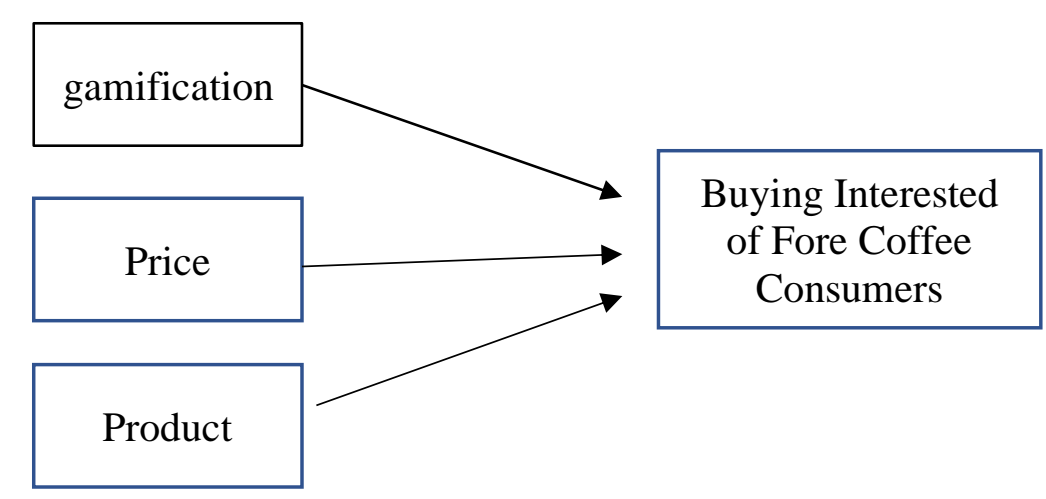

Figure 1. Conceptual Model 


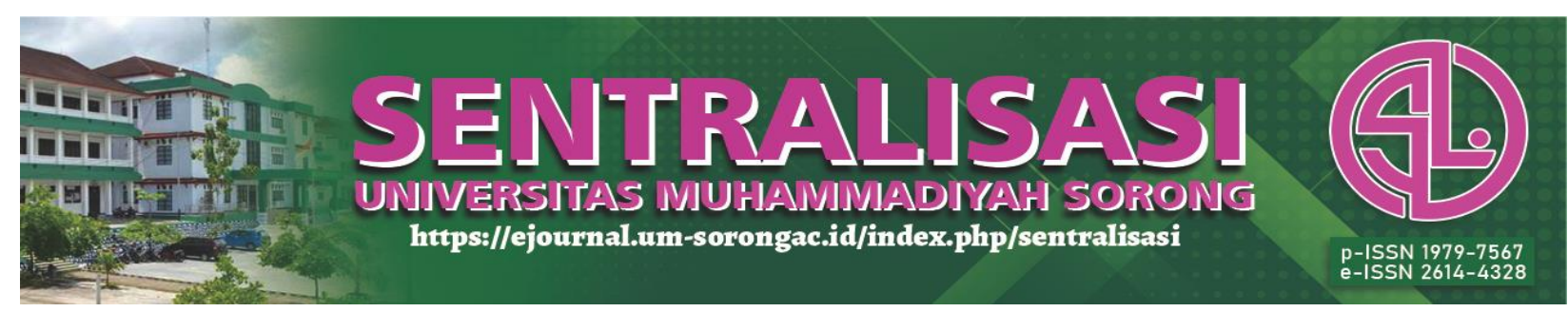

The hypothesis of this research is:

H1: Gamification has a positive effect on buying interest of Fore coffee consumers

$\mathrm{H} 2$ : Price has a positive effect on buying interest of Fore coffee consumers

H3: Product has a positive effect on buying interest of Fore coffee consumers

\section{Results and Discussion}

The number of respondents who have participated in this study amounted to 120 respondents. Because those who fill out this questionnaire are limited to consumers who have fore coffee applications. Of the 120 selected respondents, 100 respondents filled in completely. The following is a description of each respondent's data based on the questionnaires that have been distributed.

Table 1. Description of Respondents

\begin{tabular}{ll}
\hline Category & Percentage \\
\hline Gender & $66 \%$ \\
Man & $34 \%$ \\
Woman & \\
Age & $39 \%$ \\
$17-21$ Years & $57 \%$ \\
$22-26$ years old & $18 \%$ \\
$>$ 36 Years & \\
Work & $64 \%$ \\
Student & $10 \%$ \\
Private employees & $16 \%$ \\
Businessman & $10 \%$ \\
Others & \\
Frequently used coffee apps & $48 \%$ \\
Kopi Kenangan & $52 \%$ \\
Fore Coffee & \\
Frequency of using App Points & $23 \%$ \\
often & $77 \%$ \\
Seldom &
\end{tabular}

Source: Data processed, 2021

Based on table 1, it shows that there are more female respondents than male with a percentage of $66 \%$ for female respondents and $34 \%$ for male respondents. The majority of respondents who filled out this questionnaire had an age range of 17-21 years as many as 39\%, followed by those aged 


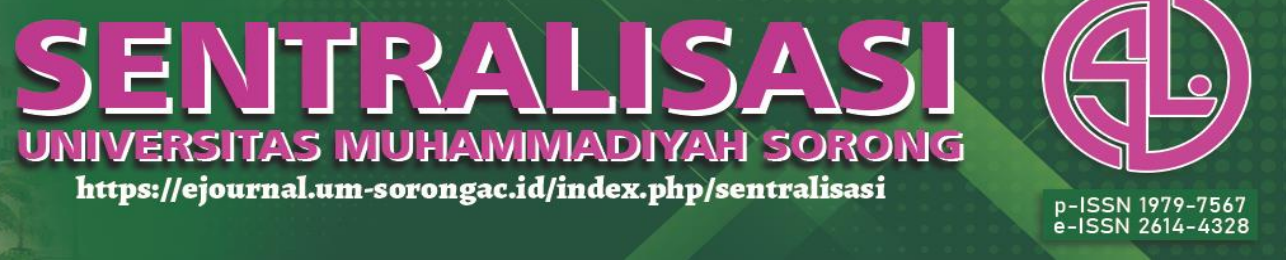

$22-26$ years as many as $57 \%$ or 57 people and ages over 27 years as many as $18 \%$ or 18 people. Most of the respondents who filled out this questionnaire were students by $64 \%$, then there were private employees as much as $10 \%$, entrepreneurs by $16 \%$ and the remaining $10 \%$ with other professions that were not mentioned. From the table it is also known that the fore coffee application is more widely used than its competitor applications. As many as $52 \%$ use the fore coffee application and the remaining $48 \%$ use the memory coffee application. Structural equation modeling (SEM)-Rartial least squares (PLS) was used for answering the validity of the framework and hypothesis testing. The main purpose of the selection of PLS is because of its ability to predict the model created ((Shmueli et all, 2019). The model of SEM-PLS is evaluated in two steps: First, analysis of the outer model to ensure that the measurements used are valid and reliable. Second, Inner Analysis of the model to evaluate the structural model.

Tabel 2. The Result of Outer Model

\begin{tabular}{cccccc}
\hline Variabel & Indikator & $\begin{array}{c}\text { Factor } \\
\text { loading }\end{array}$ & $\begin{array}{c}\text { Cronbach's } \\
\text { Alpha }\end{array}$ & $\begin{array}{c}\text { Composite } \\
\text { reability }\end{array}$ & AVE \\
\hline gamification & GM1 & 0,864 & 0,714 & 0,874 & 0,777 \\
& GM2 & 0,899 & & & \\
Price & PR1 & 0,813 & 0,908 & 0,908 & 0,711 \\
& PR2 & 0,802 & & & \\
& PR3 & 0,866 & & 0,909 & 0,667 \\
Product & PR4 & 0,889 & & & \\
& VP1 & 0,776 & 0,909 & & \\
& VP2 & 0,879 & & & \\
Buying & VP3 & 0,859 & & & \\
& VP4 & 0,847 & & 0,871 & \\
& VP5 & 0,710 & & & \\
& MB1 & 0,794 & 0,871 & & \\
& MB2 & 0,794 & & & \\
& MB3 & 0,816 & & & \\
\end{tabular}

Source: Data processed, 2021

\section{Validity and Reliability Test Results.}

Table 2. shows that Cronbach's Alpha on each variable has a value of more than 0.70 , meaning that all of variables in this study are reliable or the respondents' answers are consistent. To determine validity, the author uses a method by looking at the loading factor for each indicator. It can be seen in the table above which shows that all measuring instruments in this study have a factor value of more than 0.60 . 

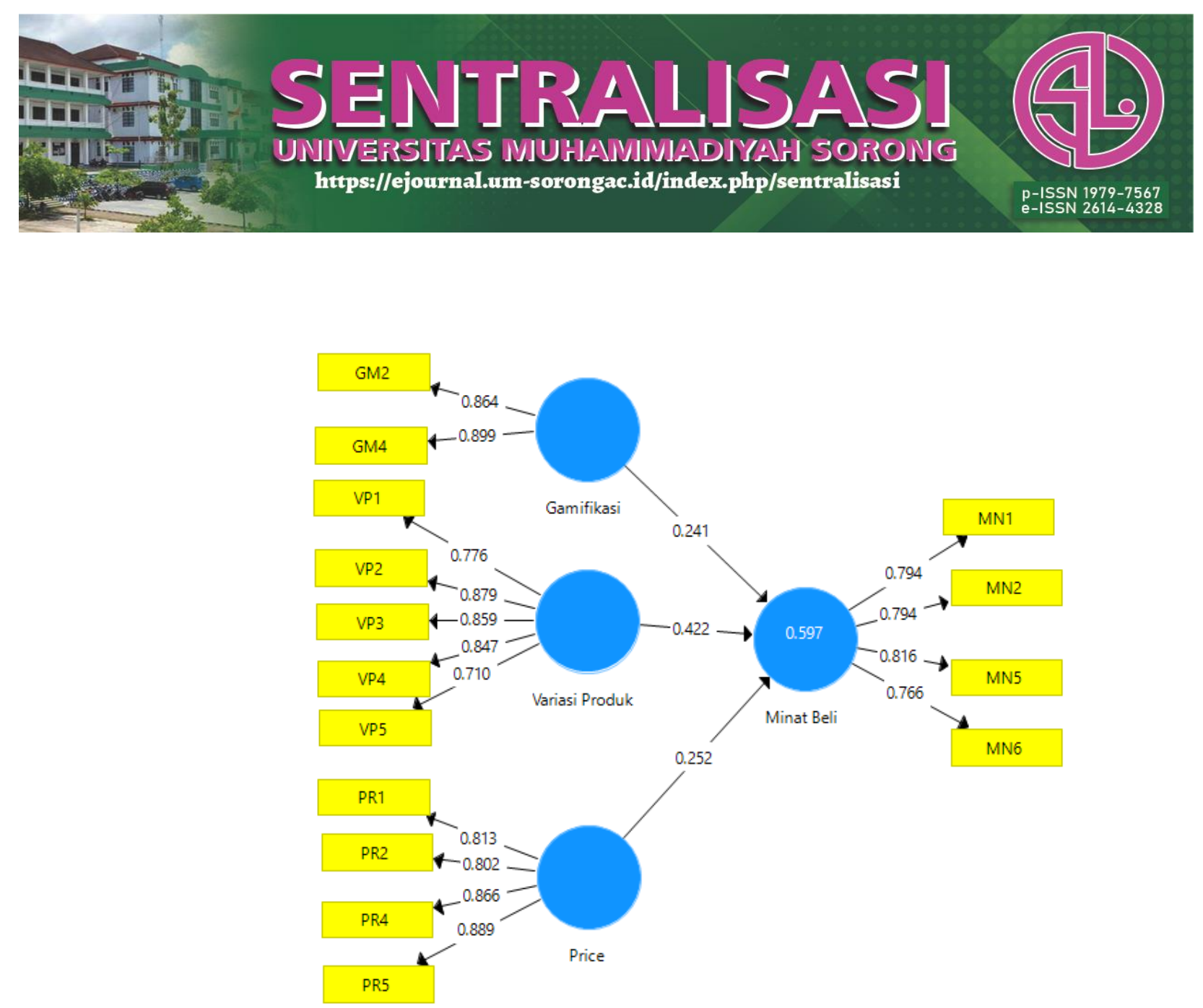

Figure 2. Hypothesis Test Results Model

Table 3. Test Results of Hypothesis

\begin{tabular}{llll}
\hline \multicolumn{1}{c}{ Hipotesis } & \multicolumn{1}{c}{ T- } \\
& Statistik & P-value & \multicolumn{1}{c}{ Kesimpulan } \\
\hline H1: gamification (X) --> Buying Interest (Y) & 2.934 & 0.000 & Hypothesis is Accepted \\
H2: Price (X) --> Buying Interest (Y) & 1.940 & 0.953 & Hypothesis is Rejected \\
H1: Product (X) --> Buying Interest (Y) & 3.646 & 0.000 & Hypotesis is Accepted \\
\hline
\end{tabular}

Source: Data processed, 2021

Based on the table 3, T-value for the gamification variable is 2,934, which is greater than 1.96. It means that the effect of gamification on buying interest fore coffee is significant. The gamifications contained in the fore coffee application have an influence on consumer buying interest, seen from the results of hypothesis testing $(\mathrm{p}<0.001)$. The results of this study are in line with (Chrisnathaniel et al, 2020) which explains that Shopee.com gamification has a positive effect on repurchase intentions.

Variables products has a significant influence on consumer buying interest Fore coffee with a Tstatistic value of 3.646 which is greater than 1.96. The products contained in the fore coffee application have an influence on consumer buying interest, seen from the results of hypothesis testing $(\mathrm{p}<0.001)$. The results obtained in this study are in accordance with the results of previous 


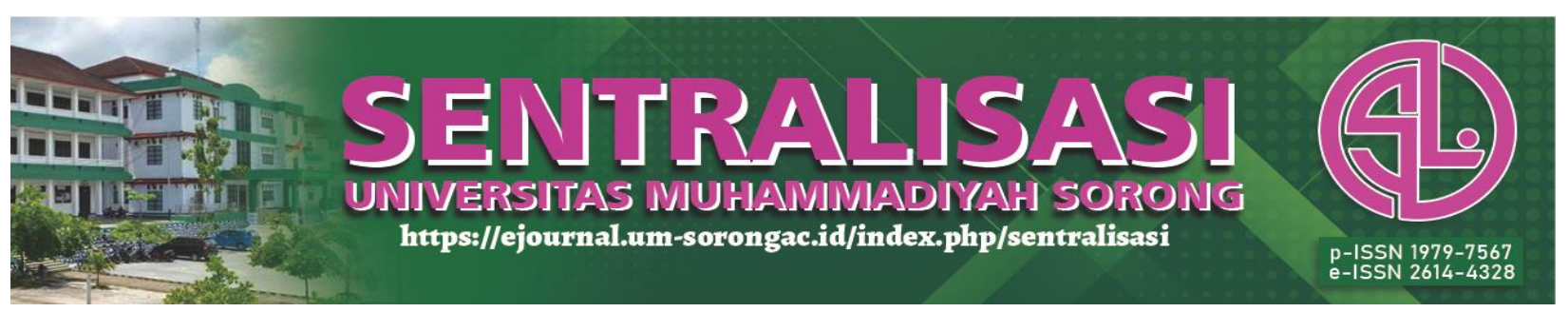

studies that have been carried out by(Irawan, 2021) shows that the product variable has a positive and significant effect on buying interest Coffee On Online Application.

However, the price variable has a value of 1.94 which is smaller than 1.96, meaning that the variable of price had no influence on buying interest of fore coffee consumers. From the results of hypothesis testing, it shows that the price is not significant to the buying interest of fore coffee consumers $(p>0.0001)$. The results of this reseach validate the model of other research findings(Sumi \& Kabir, 2018). This research has found that consumers will spend a money for quality goods, businesses can charge prices when consumer confidence in the product has been achieved. Fore coffee must immediately determine and adjust prices, in order to increase consumer buying interest.

\section{Conclusion}

The Gamifications contained in the fore coffee application have an influence on consumer buying interest, seen from the results of testing the proposed model hypothesis. The T-value for the gamification variable is 2,934 , which is greater than 1.96 . The products contained in the fore coffee application have an influence on consumer buying interest, seen from the results of hypothesis testing with a Tstatistic value of 3.646 which is greater than 1.96. Hypothesis testing shows that the price is not significant to the buying interest of fore coffee consumers with a value of 1.94 which is smaller than 1.96 .

Practical implications for business people, There are some limitations in this study. One of the limitations is that this study only uses a limited sample of respondents. However, with this limited sample, there are findings that can be used to gain a better understanding of gamification in consumer buying interest.Therefore, our advice to fore coffee is to add gamification features in addition to points and must seriously develop other game designs on the application, recruit or consult professional game designers, to create attractive games around products and service. For further research, it can be developed by increasing the number of samples of other gamification benefits that are embedded in online shopping applications, so that they can add to the repertoire of knowledge in the world of digital marketing.

\section{Reference}

Alflayyeh, S., Ali Belhaj, F., \& Professor, A. (2020). The Impact Of Coronavirus (Covid-19) Pandemic On Retail Business In Saudi Arabia: A Theoretical Review. Europran Journal of Molecular \& Clinical Medicine, 7(1), 3547-3554.

Alfred, O. (2013). Influences of Price And Quality On Consumer Purchase Of Mobile Phone In The Kumasi Metropolis In Ghana A Comparative Study. European Journal of Business and Management, 5 (1),. 


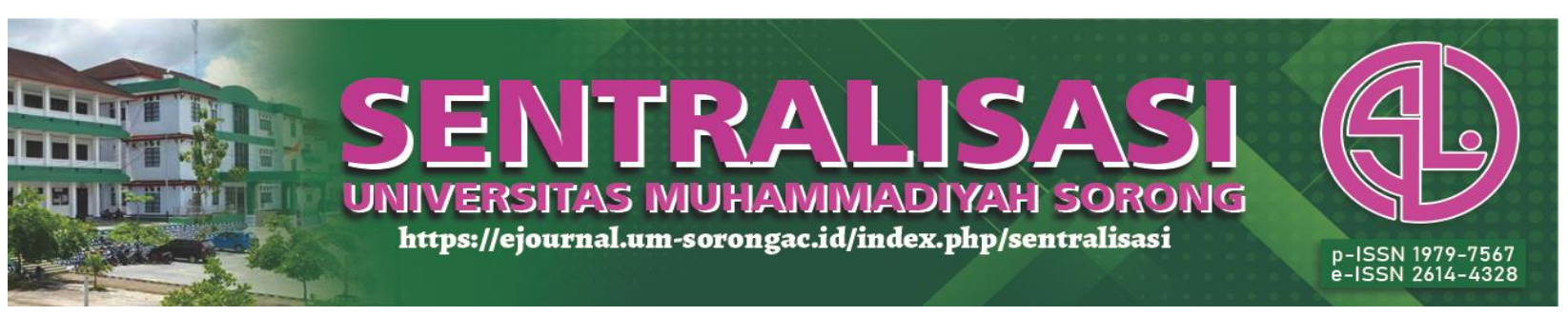

Arikunto. (2015). Prosedur Penelitian Suatu Pendekatan Praktik. Rineka Cipta.

Chrisnathaniel, H. C., Hartini, S., \& Rahayu, S. P. (2020). Jurnal Nusantara Aplikasi Manajemen Bisnis Jurnal Nusantara Aplikasi Manajemen Bisnis. Analisis Determinan Loyalitas Pengunjung Di Perpustakaan Kota X, 5(2), 256-264.

Dunakhe, K., \& Panse, C. (2020). Impact of digital marketing - a bibliometric review. https://doi.org/10.1108/IJIS-11-2020-0263

Hamari, J. (2015). Why do people use gamification services? International Journal of Information Management, 35(4), 419-431. https://doi.org/10.1016/j.ijinfomgt.2015.04.006

Hamari, Juho, Koivisto, J., \& Sarsa, H. (2014). Hks14. Proceedings of the Annual Hawaii International Conference on System Sciences, January(6-9), 3025-3034.

Irawan, I. A. (2021). Pengaruh Kualitas Produk, Citra Merek dan Harga Terhadap Keputusan Pembelian Kopi Pada Aplikasi Online Dimasa Pandemi Covid-19. Jurnal Ilmiah Manajemen, 7(1).

Kotler dan Gary Armstrong. (2012). Prinsip-prinsip Pemasaran (Edisi 13.).

Roggeveen, A. L., \& Sethuraman, R. (2020). How the COVID-19 Pandemic May Change the World of Retailing. Journal of Retailing, 96(2), 169-171. https://doi.org/10.1016/j.jretai.2020.04.002

Schiffman, 1.G. dan Kanuk, L. L. (2013). Consumer Behavior (8th editio). New Jersey: Prentice Hall.

Shmueli, G., Sarstedt, M., Hair, J.F., Cheah, J.H., Ting, H., Vaithilingam, S. and Ringle, C. . (2019). Predictive model assessment in PLS-SEM: guidelines for using PLSpredict. European Journal of Marketing, Vol. 53 No. 11, Pp. 2322-2347.

Simanjuntak, M., Awwaliyah, I., Hayati, H., \& Artanto, R. J. (2016). The Entrepreneurial Potential among Undergraduate Students. Jurnal Bisnis Dan Manajemen, 17(2), 75-84. https://doi.org/10.24198/jbm.v17i2.29

Sumi, R. S., \& Kabir, G. (2018). Factors affecting the buying intention of organic tea consumers of Bangladesh. Journal of Open Innovation: Technology, Market, and Complexity, 4(3). https://doi.org/10.3390/joitmc4030024

Vitkauskaite, E., \& Gatautis, R. (2018). Points for Posts and Badges to Brand Advocates: The Role of Gamification in Consumer Brand Engagement. Proceedings of the Annual Hawaii International Conference on System Sciences, 2018-Janua(January), 1148-1157. https://doi.org/10.24251/HICSS.2018.143

Wolf, T., Welf, H.W. and Hammerschmidt, M. (2020). Experiences that matter? The motivational experiences and business outcomes of gamified services. Journal of Business Research, Vol. 106, Pp. 353-364.

Zhu, DH, Zhang, ZJ, Chang, YP, \& Liang, S. (2019). Good discounts earn good reviews in return? Effects of price promotion on online restaurant reviews. International Journal of Hospitality Management, 77, 178-186. Https://Doi.Org/10.1016/j.Ijhm.2018.06.028.

Zichermann, Gabe, and C. C. (2011). Gamification by design: Implementing game mechanics in 


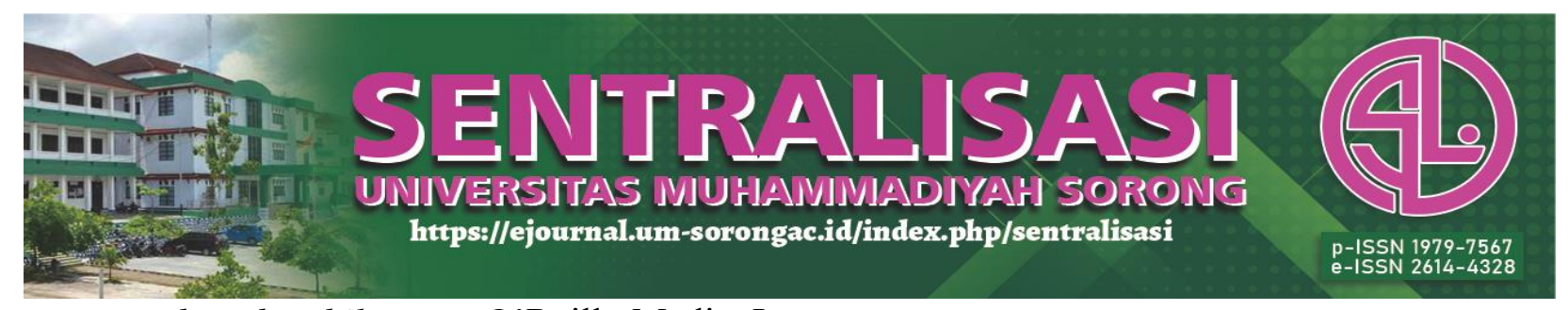

web and mobile apps. O'Reilly Media, Inc.

Zou,T. (2018). Online impulse buying behavior amongst undergraduate students in Tianjin, The People's Republic of China. ABAC Journal, 38(2), 94-113. 